Utah State University

DigitalCommons@USU

Green Canyon Environmental Research Area, Logan Utah

Quinney Natural Resources Research Library, S.J. and Jessie E.

1997

\title{
Winter Activity Patterns of American Martens (Martes americana): Rejection of the Hypothesis of Thermal-Cost Minimization
}

Gary S. Drew

John A. Bissonette

Follow this and additional works at: https://digitalcommons.usu.edu/grcanyon

Part of the Ecology and Evolutionary Biology Commons, Entomology Commons, Forest Biology Commons, Forest Management Commons, and the Wood Science and Pulp, Paper Technology Commons

\section{Recommended Citation}

Drew, G. and Bissonette, J. (1997). Winter activity patterns of American martens (Martes americana): rejection of the hypothesis of thermal-cost minimization. Can. J. Zool. 75(5): 812-816.

This Article is brought to you for free and open access by the Quinney Natural Resources Research Library, S.J. and Jessie E. at DigitalCommons@USU. It has been accepted for inclusion in Green Canyon Environmental Research Area, Logan Utah by an authorized administrator of DigitalCommons@USU. For more information, please contact digitalcommons@usu.edu.

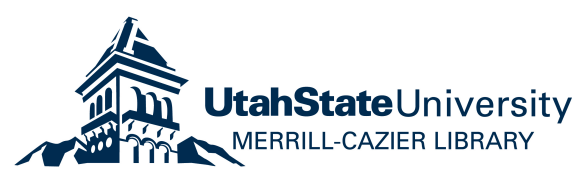




\title{
Winter activity patterns of American martens (Martes americana): rejection of the hypothesis of thermal-cost minimization
}

\author{
Gary S. Drew and John A. Bissonette
}

\begin{abstract}
Despite their temperate to subarctic geographic range, American martens (Martes americana) possess a thermally inefficient morphology. The lack of morphological adaptations for reducing thermal costs suggests that marten may use behavioral strategies to optimize thermal budgets. During the winters of 1989-1990 and 1990-1991, we radio-collared and monitored the diel activity of 7 martens. A log-linear model suggested that the presence or absence of light was the only factor associated with marten activity patterns $(p<0.001)$. A regression of the percentage of active fixes on ambient temperature failed to detect an association $(b=-4.45, p=0.084, n=12)$. Contents of marten scats suggested that their activity was consistent with the prey-vulnerability hypothesis. While martens must balance multiple life requisites, their activity patterns suggest that they accept increased thermal costs in order to increase foraging efficiency. However, the nocturnal activity of martens during winter was also consistent with the hypothesis that they may be able to limit their own exposure to predation risk. The nocturnal habits of Newfoundland martens in the winter were consistent with the hypothesis of avoidance of predation risk.
\end{abstract}

Résumé : En dépit de sa répartition géographique étendue, de la zone tempérée à la région subarctique, la Martre d'Amérique (Martes americana) ne possède pas une morphologie qui lui assure une bonne efficacité thermique. L'absence d'adaptations morphologiques qui lui permettent de minimiser ses coûts thermiques nous porte à croire que la martre utilise des stratégies comportementales pour optimiser son budget thermique. Au couros des hivers de 1989-1990 et 1990-1991, nous avons muni sept martres de colliers émetteurs et avons enregistré leurs activités journalières. Un modèle log-linéaire que la présence ou l'absence de lumière constitute le seul facteur relié à l'emploi du temps des martres $(p<0,001)$. L'examen d'une régression entre les pourcentages d'activité et la température ambiante n'a mis en lumière aucune association entre les deux facteurs $(b=-4,45, p=0,084, n=12)$. Le contenu des fèces indique que l'activité des martres semble correspondre à l'hypothèse de la vulnérabilité des proies. Il est évident que les martres doivent faire un partage équilibré de leurs besoins vitaux, mais leurs patterns d'activité semblent indiquer qu'elles sont prêtes à accepter une augmentation de leurs coûts thermiques en échange d'une augmentation de l'efficacité de leur recherche de nourriture. Cependant, l'activité nocturne des martres en hiver peut également avoir pour effet de réduire les risques de prédation. Les habitudes nocturnes des martres de Terre-Neuve en hiver ne contredisent pas l'hypothèse de la fuite des riques de prédation. [Traduit par la Rédaction]

\section{Introduction}

Animals living in thermally stressful environments typically acquire morphological, physiological, or behavioral adaptations to assist in thermal regulation (Chappell 1980). With

Received July 29, 1996. Accepted November 20, 1996.

G.S. Drew ${ }^{1}$ and J.A. Bissonette. National Biological Service, Utah Cooperative Fish and Wildlife Research Unit, Department of Fisheries and Wildlife, Utah State University, Logan, UT 84322-5210, U.S.A

1 Present address and author to whom all correspondence should be sent: National Biological Service, Alaska Science Center, 1011 East Tudor Road, Anchorage, AK 99516, U.S.A. (e-mail: gary_drew@nbs.gov).
American martens (Martes americana), adaptations for predatory efficiency, i.e., a long thin body, minimal body fat reserves, and a short pelage, allow them to enter confined spaces in search of small prey but exact a high toll in homeothermic efficiency (Brown and Lasiewski 1972; SchmidtNielson 1983; Buskirk et al. 1988). Laboratory studies have found the minimum critical temperature (MCT) for martens to range from $16^{\circ} \mathrm{C}$ (Buskirk et al. 1988; W.A. Adair and J.A. Bissonette, unpublished data) to $29^{\circ} \mathrm{C}$ (Worthen and Kilgore 1981). Below the MCT, martens must increase their metabolic rate at rest to compensate for heat loss. Given their adaptive constraints, martens would be expected to minimize their exposure to temperatures below their MCT.

The results of studies of marten activity in both Alberta (More 1978) and Ontario (Thompson and Colgan 1994) appear to support this hypothesis, with martens in these areas 
adopting predominantly diurnal activity patterns during the winter. In contrast, Zielinski et al. (1983) and Martin (1987) found martens in California to be primarily diurnal during the summer and nocturnal during the winter. Zielinski et al. (1983) suggested that the adoption of nocturnal activity patterns by martens in their study area during the winter could be a result of the synchronizing of their activity with that of their prey. Additionally, in controlled experiments, minks (M. erminea) and weasels ( $M$. nivalis) were found to shift their foraging activity to take advantage of greater prey vulnerability (Zielinski 1988). One point of general agreement is that the total time martens spend active is lower during the winter (More 1978; Zielinski et al. 1983).

We examined the activity patterns of martens during the winter in an effort to resolve the differences in activity patterns described by previous researchers. The first and simplest hypothesis, that martens attempt to minimize their exposure to the lowest temperatures (i.e., decrease their activity with decreasing ambient temperature), would be consistent with what is known about marten physiology (Buskirk et al. 1988; W.A. Adair and J.A. Bissonette, unpublished data) (Worthen and Kilgore 1981) and what was found by More (1978) in Alberta and Thompson and Colgan (1994) in Ontario. If, instead, martens in Newfoundland fail to minimize their activity during periods when ambient temperatures fall below their MCT, as has been observed in California (Zielinski et al. 1983 and Martin 1987), we wanted to examine whether our data were consistent with the preyvulnerability hypothesis put forward by Zielinski et al. (1983). This hypothesis postulates that martens are active during periods when their prey are most vulnerable. Additionally, we wanted to examine an alternative explanation, that martens may adjust their activity patterns to take advantage of periods when predators are less active or less efficient, thus limiting their own exposure to predation. While habitat selection by martens has been linked to the potential risk of predation (Pulliainen 1981; Thompson 1991; Drew 1995), risk avoidance has not previously been suggested as an explanation for their activity patterns. However, the temporal avoidance of predators has been demonstrated for other species (Sih 1980).

\section{Methods}

This study was conducted in the northwestern portion of the Pine Marten Study Area (PMSA) in western Newfoundland, Canada (Bissonette et al. 1989). The PMSA, located approximately $50 \mathrm{~km}$ south of Corner Brook, was set aside in 1972 to arrest the decline in martens on the island. Although no mammal trapping is allowed in the PMSA, logging operations continued until 1991. The study area is characterized by a mosaic of old-growth forest interspersed with ponds, bogs, and barrens. Primary tree species include balsam fir (Abies balsamea), black spruce (Picea mariana), and white birch (Betula papyrifera) (Snyder and Bissonette 1987). Old-growth stands contain large numbers of uprooted trees and snags. Hemlock looper (Lambdina fiscellaria) andn spruce budworm (Choristoneura fumiferana) infestations in the study area have left large defoliated stands of balsam fir. Topography is rugged, with elevations ranging from 80 to $700 \mathrm{~m}$ (Snyder and Bissonette 1987; Bissonette et al. 1988).

Eight martens ( 4 \& : 4 o') were captured in $20 \times 20 \times 50 \mathrm{~cm}$ live traps during the winters of 1989-1991. Animals were immobilized with ketamine hydrochloride $(100 \mathrm{mg} / \mathrm{mL})$ and fitted with telemetry collars (approximately $21 \mathrm{~g}$ ). However, no data were used from 1 female that slipped her collar after 2 days. Marten activity was treated as a dichotomous variable: active or not active. Activity was determined by evaluating the variation in the telemetry signal. Signals with erratic strength and pitch indicated active animals (Sunquist and Montgomery 1973; Zielinski et al. 1983). These measurements were taken during daily telemetry relocations and during activity monitoring sessions conducted at all hours of the day and night. Observations were separated by a minimum of $30 \mathrm{~min}$ and grouped into 2-h blocks, following the protocol of Zielinski et al. (1983). The percentage of fixes within each $2-\mathrm{h}$ block was calculated and used as a representation of the activity level of the 7 monitored martens. Log-linear models were used to test for variation in marten activity due to the following factors: individual $(n=7)$, age-class $(n=2)$, sex $(n=2)$, and presence or absence of light $(n=2)$. Temperature was not included in the log-linear models because of the obvious covariance with light. We tested for dependency of marten activity level on temperature with a regression analysis. A significant result with a positive slope would support the hypothesis that martens are primarily constrained by thermal conditions. Conversely, a lack of correlation, or a slope other than positive, would indicate that martens were trading thermal efficiency for some other factor. Subnivean temperatures were not recorded because snow depth averaged over $1 \mathrm{~m}$ during the study period and numerous studies have demonstrated the generally constant subnivean temperatures ranging from -5 to $-0^{\circ} \mathrm{C}$ at this depth (Merritt 1984; Salisbury 1984).

To estimate the food habits of martens, we collected scats encountered while snow tracking radio-collard martens. Although the number of scats precluded any statistical analysis, they were from the trails of known martens, giving us confidence that they provide an accurate representation of food habits. In addition, we drew on the results of a marten diet study conducted in our study area during the winter of 1986-1987 (Tucker 1988). The frequency of occurrence of prey in scats was used to quantify marten diet components so that our results could be related to the previous study. To estimate the importance of these prey we averaged the frequencies between the two studies, then multipled each frequency by the caloric value determined by Powell (1993) for fishers (Martes pennanti). Additionally, we weighted these three primary prey species according to the probability of each being expressed in more than 1 scat. The weighting was 1.0 for meadow vole, 0.5 for red squirrel, and 0.33 for snowshoe hare.

The presence of potential predators was determined by direct observation, tracks, and a raptor-call count in the winter of $1990-$ 1991. Although we lacked the resources to closely monitor potential predators, call counts and daily inspection of tracks along trails enabled us to determine which predators were in the area and to qualitatively evaluate the potential of the risk-avoidance hypothesis.

\section{Results}

In total, 273 activity measurements were made on 7 telemetered martens $(\bar{x}=41.5, \mathrm{SD}=49.5)$ from January to March of 1989 and 1990. Within each 2-h block, 23 measurements were made, on average. The best fit log-linear model (light) (Table 1) indicated that the activity levels of martens were lower during daylight hours than at night. The number of marten monitored was small (7); however, a log-linear model failed to detect any significant variation in activity patterns of individuals (light, activity, individual) (Table 1). Neither sex nor age was found to be a significant factor, although juveniles and males did display slightly higher activity rates than adults and females, respectively. A lack of differences between individual activity periods led us to group all activity data for regression. However, this 
Table 1. Results of log-linear models used to examine potential causes of the activity patterns of martens in the Little Grand Lake arca of Newfoundland during the winters of 1989-1990 and $1990-1991$.

\begin{tabular}{lccc}
\hline \multicolumn{1}{c}{ Model } & df & $\begin{array}{c}\text { Parameter } \\
\text { estimate }\end{array}$ & $\begin{array}{c}\text { Likelihood-ratio } \\
\chi^{2}\end{array}$ \\
\hline Age & 1 & 0.49 & 0.47 \\
Light & 1 & $* * *$ & 25.60 \\
Sex & 1 & 0.19 & 1.71 \\
Age $\times$ light & 1 & 0.69 & 0.16 \\
Sex $\times$ light & 1 & 0.63 & 0.21 \\
Individual $\times$ light & 6 & 0.46 & 5.70 \\
\hline \multirow{2}{*}{$* * p<0.001}$. & &
\end{tabular}

regression of mean activity level on temperature for each 2 -h sampling block was not significant $(p=0.084)$, indicating that marten activity did not vary with ambient temperature. A plot of these winter activity patterns indicated that martens in the study were predominantly nocturnal (Fig. 1). The nearly inverse relationship between marten activity and ambient temperature was likely due to the dependency of temperature on insolation.

Analysis of scats collected from the trails of tracked martens indicated relative agreement between our sample of scats and that collected by Tucker (1988) (Table 2). After correction for the value of each prey (calories) and its likelihood of being excreted in more than 1 scat, we found that red squirrel (Tamiasciurus hudsonicus) was the most important component of marten diets in the study area, followed by snowshoe hare (Lepus americanus) and meadow vole (Microtus pennsylvanicus) (Table 2). Activity patterns of prey species derived from the literature indicated that martens synchronized their activity with that of hares but not red squirrels or voles.

Raptor-call counts failed to reveal any potential avian predators at the study area during the winter of 1990-1991. However, red fox tracks were detected on a daily basis. During our study 1 marten was predated by a red fox. Lynx (Felis lynx) tracks were also detected near the edge of the study area on one occasion. Previous research in the same study area recorded 3 related mortalities, 1 attributed to red fox, 1 to a raptor, and 1 to unknown causes (Bissonette et al. 1988). Given the small number of martens monitored in the two studies, predation appeared to be a major source of mortality for martens in the study area.

\section{Discussion}

Martens are under significant thermal stress during the winter. A lack of significant morphological or physiological adaptations for thermal efficiency suggests that martens must regulate their thermal costs through either behavioral means or increased consumption of prey. Although martens do select and use thermally efficient subnivean resting sites (Buskirk 1984; Buskirk et al. 1989), because of the stability of subnivean temperatures the thermal benefits of these sites are dependent on ambient temperature. Maximum thermal benefit would be gained by resting during the coldest portions of the day. Chappell (1980) estimated that arctic animals, including ermine (Mustela erminea), could save an average of $30 \%$ of their thermoregulatory costs by leaving their burrows only on sunny days. Hence, during the winter, when martens are faced with high thermodynamic costs, they could limit thermal maintenance costs by using subnivean resting points during the night and confining their activity to daylight hours.

However, our data, as well as the results of studies conducted in California (Zielinski et al. 1983; Martin 1987), indicate a pattern of primarily nocturnal activity during the winter months. While this is at odds with the results of More's (1978) study in Alberta and Thompson and Colgan's (1994) study in Ontario, climatological data indicate that mean ambient temperatures in January are lower in both More's and Thompson and Colgan's study areas in central Canada $\left(-17.5^{\circ} \mathrm{C}\right)$ than in marten study areas in either California $\left(0^{\circ} \mathrm{C}\right)$ or Newfoundland $\left(-7.5^{\circ} \mathrm{C}\right)$ (World Meteorological Organization 1979). These differences suggest a temperature threshold that may be exceeded at higher latitudes and altitudes, where thermal constraints may take precedence over other factors influencing marten activity patterns.

Zielinski et al. (1983) suggested that the thermally inefficient activity patterns of martens they studied in California could be related to a strategy used by the martens to increase hunting efficiency by synchronizing their activity patterns with those of their primary prey species. This hypothesis would seem to require that a major portion of marten diets be composed of species with nocturnal activity patterns similar to those of marten. In our study the most important prey species found in scats from the winter of 1990-1991, as in the previous food-habits study in the same area (Tucker 1988), were red squirrels, which are diurnal. However, Zielinski et al. (1983) also suggested that red squirrels could be an exception, becoming more vulnerable when resting in subnivean middens. Snowshoe hares were nocturnal and the second most important prey item in the study. Hence, martens in Newfoundland behaved in a manner consistent with Zielinski et al's (1983) prey-vulnerability hypothesis. However, we have some reservations about the assertion that red squirrels are more vulnerable when inactive, making them an exception to the general synchronization hypothesis. The suggestion that red squirrels may be more vulnerable to predation at night, when they are inactive, has not been tested. Clarification of this relationship would aid in explaining marten behavior.

Predation offers another potential explanation for the adoption of nocturnal activity patterns, by Newfoundland martens. Martens are relatively long-lived, and reach sexual maturity late; hence, they should seek to minimize mortality risks. Martens could limit their own exposure to predation by being active when predators are less active or efficient. Nocturnal behavior has been cited as an adaptation for limiting exposure to predation risk. Low-light conditions should have less effect on the hunting patterns of martens, which are predominantly subnivean, than on the efficiency of potential supernivean marten predators, e.g., red fox. Additionally, the 4 marten mortalities attributed to predation indicate that martens are at substantial risk. Although we were unable to resolve the paradox of marten activity patterns, we were able to determine that martens in Newfoundland were not minimizing their thermal costs. They were behaving in a manner consistent with the prey-vulnerability hypothesis put forward by Zielinski et al. (1983) and the predation-risk hypothesis. 
Fig. 1. Diel activity patterns of martens at Little Grand Lake, Newfoundland, during the winters of 1989-1990 and 1990-1991. The curve represents mean temperatures over the diel period. The bars indicate average activity levels of martens.

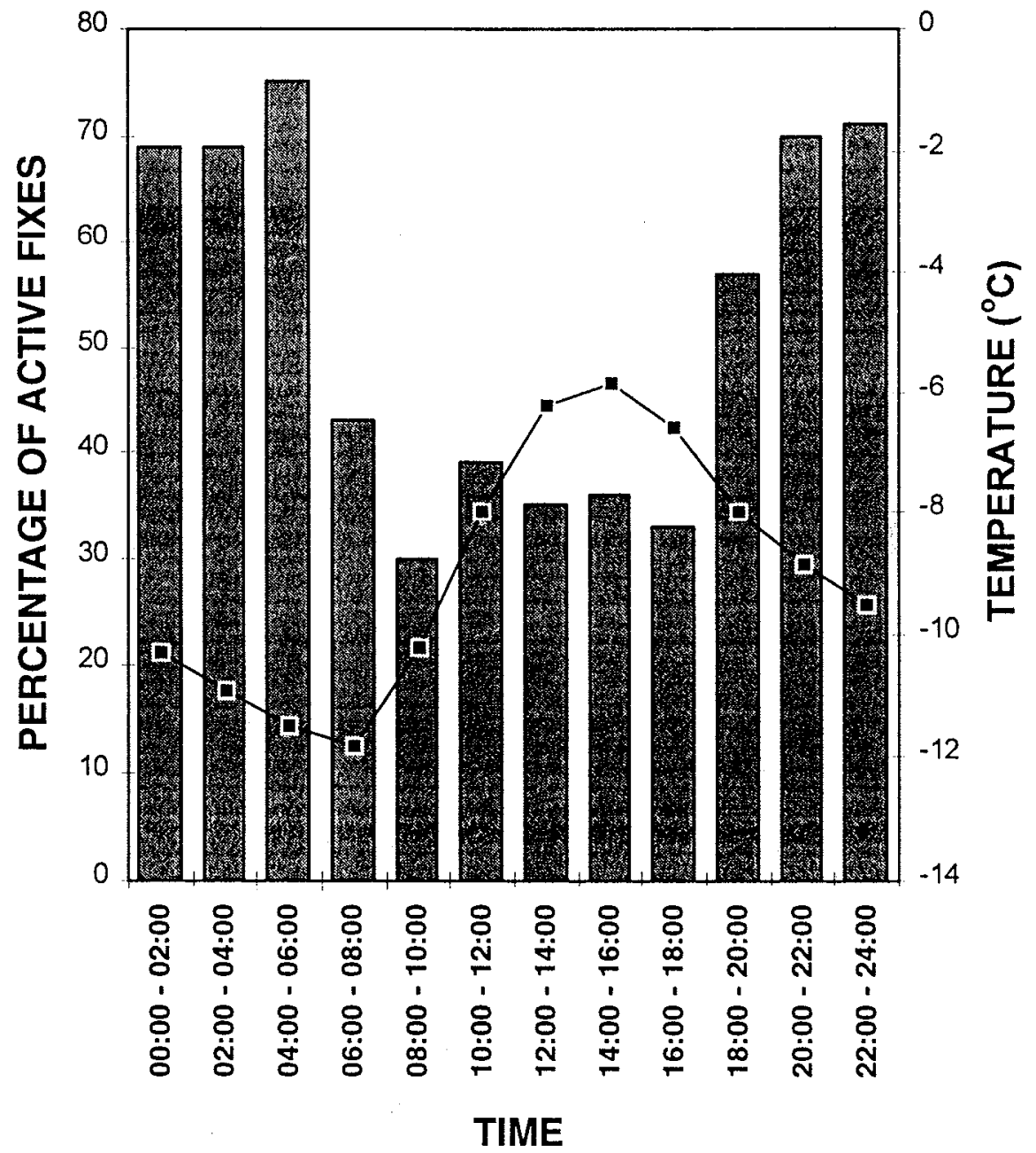

Table 2. Activity patterns of marten prey present in the Little Grand Lake area of western Newfoundland and the frequency of occurrence of prey items in scats collected during the winters of $1986-1987$ and $1990-1991$.

\begin{tabular}{|c|c|c|c|c|}
\hline \multirow[b]{2}{*}{ Prey } & \multirow[b]{2}{*}{$\begin{array}{c}\text { Winter } \\
\text { activity pattern }\end{array}$} & \multicolumn{2}{|c|}{ Occurrence in scats (\%) } & \multirow{2}{*}{$\begin{array}{c}\text { Estimated energy } \\
\text { metabolized }^{b} \\
(\mathrm{kcal})\end{array}$} \\
\hline & & $\begin{array}{c}1990-1991 \\
(n=12)\end{array}$ & $\begin{array}{c}1986-1987 \\
(n=30)^{a}\end{array}$ & \\
\hline Lepus americana & Nocturnal $^{c}$ & 8.3 & 3.3 & 2900 \\
\hline Microtus pennsylvanicus & All times ${ }^{d, e}$ & 50.0 & 66.7 & 1750 \\
\hline Peromyscus maniculatus & Nocturnal $^{e}$ & 0 & - & - \\
\hline Sorex cinereus & All times ${ }^{c}$ & 16.7 & 23.0 & - \\
\hline Tamiasciurus hudsonicus & Diurnal $^{c}$ & 16.7 & 20.0 & 4588 \\
\hline Birds & Diurnal & 33.3 & 10.5 & - \\
\hline Carrion & None & 8.3 & 0.1 & - \\
\hline Vegetation & None & 33.3 & 13.3 & - \\
\hline
\end{tabular}

${ }^{a}$ From Tucker (1988).

"From Powell (1993).

${ }^{c}$ From Banfield (1974).

${ }^{d}$ From Madison (1984).

${ }^{e}$ From Stebbins (1984), 
We suggest that these studies indicate two important points. First, martens appear to be behaviorally plastic in their activity patterns. The environmental constraints placed upon martens may limit them to a narrow range of responses and preclude a stereotypical winter activity pattern. Secondly, these behaviors may not be explained by any single hypothesis. The winter activity of American martens may depend on a combination of factors, including ( $i$ ) energy costs, (ii) energy acquisition, and (iii) avoidance of mortality risk. Detailed research on the trade-offs between these factors will be necessary to allow the decision-making processes of martens to be better understood.

\section{Acknowledgments}

The Newfoundland and Labrador Wildlife Division and the World Wildlife Fund-Canada provided funds for this study. The cooperation and assistance of Wildlife Division employees was invaluable to the project. In particular we thank Jim Hancock for his long-term support for marten research on the island of Newfoundland, and Lem Mayo and Bill Green for their field expertise and assistance.

\section{References}

Banfield, A.W.F. 1974. The mammals of Canada. National Museum of Natural Sciences and University of Toronto Press, Toronto, Ont.

Bissonette, J.A., Fredrickson, R.J., and Tucker, B.J. 1988. The effects of forest harvesting on marten and small mammals in western Newfoundland. Report prepared for the Newfoundland and Labrador Wildlife Division, and Corner Brook Pulp and Paper Company, Limited by the Utah Cooperative Fish and Wildlife Research Unit, Utah State University, Logan.

Bissonette, J.A., Fredrickson, R.J., and Tucker, B.J. 1989. American marten: a case for landscape management. Trans. N. Am. Wildl. Nat. Resour. Conf. 54: 89-101.

Brown, J.H., and Lasiewski, R.C. 1972. Metabolism of weasels: the cost of being long and thin. Ecology, 53: 939-943.

Buskirk, S.W. 1984. Seasonal use of resting sites by marten in south-central Alaska. J. Wildl. Manage. 48: 950-953.

Buskirk, S.W., and MacDonald, S.O. 1984. Seasonal food habits of marten in south-central Alaska. Can. J. Zool. 62: 944-950.

Buskirk, S.W., Harlow, H.J., and Forrest, S.C. 1988. Temperature regulation in American marten (Martes americana) in winter. Natl. Geogr. Res. 4: 208-218.

Buskirk, S.W., Forrest, S.C., Raphael, M.G., and Harlow, H.J. 1989. Winter resting ecology of marten in the central Rocky Mountains. J. Wildl. Manage. 53: 191-196.

Chappell, M.A. 1980. Thermal energetics and thermoregulatory costs of small arctic animals. J. Mammal. 61: 278-291.

Drew, G.S. 1995. Winter habitat selection by American marten (Martes americana) in Newfoundland: Why old growth? Ph.D. dissertation, Utah State University, Logan.

Madison, D.M. 1984. Group nesting and its ecological and evolutionary significance in overwintering microtine rodents. Carnegie Mus. Nat. Hist. Spec. Publ. No. 10. pp. 267-274.

Martin, S.K. 1987. The ecology of the pine marten (Martes americana) at Sagchen Creek, California, Ph.D. dissertation, University of California, Berkeley.

Merritt, J.F. 1984. Growth patterns and seasonal thermogenesis of Clethrionomys gapperi inhabiting the Appalachian and Rocky Mountains of North America. Carnegie Mus. Nat. Hist. Spec. Publ. No. 10. pp. 201-213.

More, G. 1978. Ecological aspects of food selection in pine marten. M.S. thesis, University of Alberta, Edmonton.

Powell, R. 1993. The fisher: life history, ccology, and behavior. University of Minnesota Press, Minneapolis.

Pulliainen, E. 1981. Winter habitat selection, home range, and movements of the pine marten Martes martes in a Finnish Lapland forest. In Worldwide Furbearer Conference: Proceedings, Frostburg, Md., 3-11 August 1980. Vol. 2. Edited by J.A. Chapman and D. Pursley. Worldwide Furbearer Conference, Inc.

Salisbury, F.B. 1984. Light conditions and plant growth under snow. Carnegie Mus. Nat. Hist. Spec. Publ. No. 10. pp. 39-50.

Schmidt-Nielson, K. 1983. Animal physiology: adaptation and environment. Cambridge University Press, New York.

Sih, A. 1980. Predators and prey lifestyles: an evolutionary overview. In Predation: direct and indirect impacts on aquatic communities. Edited by W.C. Kerfoot and A. Sih. University Press of New England, Hanover, N.H. pp. 203-224.

Snyder, J.E., and Bissonette, J.A. 1987. Marten use of clearcuttings and residual forest stands in western Newfoundland. Can. J. Zool. 65: 169-174.

Stebbins, L.L. 1984. Overwintering activity of Peromyscus maniculatus, Clethrionomys gapperi, C. Rutilus, Eutamias amoenus, and Microtus Pennsylvanicus. Carnegie Mus. Nat. Hist. Spec. Publ. No. 10. pp. 301-314.

Sunquist, M.E., and Montgomery, G.G. 1973. Activity patterns and rates of movement of two-toed and three-toed sloths (Choloepus hoffinani and Bradypus infuscatus). J. Mammal. 54: 946-954.

Thompson, I.D. 1991. Could marten become the spotted owl of eastern Canada? For. Chron. 67: 136-140.

Thompson, I.D., and Colgan, P.W. 1994. Marten activity in uncut and logged boreal forests in Ontario. J. Wildl. Manage. 58: $280-288$.

Tucker, B.J. 1988. The effects of forest harvesting on small manmals in western Newfoundland and its significance to marten. M.S. thesis, Utah State University, Logan.

World Meteorological Organization. 1979. Climatic atlas of North and Central America. World Meteorological Organization, Geneva.

Worthen, G.L., and Kilgore, D.L. 1981. Metabolic rate of pine marten in relation to air temperature. J. Mammal. 62: 624-628.

Zielinski, W.J. 1988. The influences of daily variation in foraging cost on the activity of small carnivores. Anim. Behav. 36: $239-249$.

Zielinski, W.J., Spencer, W.D., and Barrett, R.H. 1983. Relationship between food habits and activity patterns of pine martens. J. Mammal. 64: 387-396. 